Normativiteten garanterer ikke, at talehandlinger forbliver uimodsigeligt sande, eftersom livets modsætningsfyldthed åbenbarer aporier, der fremtræder bag om alle regler og love. Det gode liv opnås ikke en gang for alle igennem institutionaliseringen af retfærdigheden, men forbliver kun muligt i situeringen af en praktisk fornuft midt i konflikten. Denne fornuft ophæver ikke den konfliktuelle spænding, som er til stede overalt, hvor mennesker mødes, men fuldbyrder sig $i$ den velovervejede handling der tager ansvaret på sig i situationen. Dermed fastlægger Ricoeur i lighed med sine to åndsbeslægtede fortolkere af phronesis, Hans-Georg Gadamer og Hannah Arendt, stedet for den menneskelige eksistens: I det mellemrum, hvor fortid og fremtid brydes i et nu, ryddes en midte, hvor der er plads til at handle iblandt mennesker.

\section{Jonas Holst Sorensen}

\section{Det åbne samfund}

Karl R. Popper, Det åbne samfund og dets fjender, Bind $1+2$, oversættelse af The Open Society and Its Enemies (1945), på dansk ved Christian Svendsen, Spektrum, 2. oplag, 2002. 862 sider, 599 kr.

\section{Det åbne samfund og dets fjenders sidste} kapitel - kapitel 25: "Har historien nogen mening?" - redegør Popper for sit historiesyn og for sit syn på historikerens arbejde. Popper siger her, at modsat fx fysikeren eller samfundsvidenskabsmanden arbejder histori- keren med et endeligt datamateriale. Opstår der tvivl om fortolkningen af en bestemt begivenhed, vil man som historiker ikke kunne lave nye undersøgelser eller eksperimenter, som fysikeren eller samfundsvidenskabsmanden $\mathrm{fx}$ kan. Som historiker er man henvist til et endeligt kildemateriale, og der vil som regel kunne skrives forskellige historier ud fra det materiale, man har til rådighed - historier som ikke engang behøver at være indbyrdes forenelige. Popper slår derfor fast, at der: “... ikke findes en historie om 'fortiden, sådan som den faktisk fandt sted'; der kan kun findes historiske fortolkninger, og ingen af dem er endegyldige ..." (bind 2, s. 287).

Det kan derfor heller ikke hjælpe noget, at vi stiller spørgsmål som "Hvilken vej bevæger vi os?" eller "Hvilken rolle har historien essentielt set bestemt, at vi skal spille?". Den slags spørgsmål er historicistens, og de er irrationelle, fordi de ifølge Popper er umulige at besvare. I stedet for disse spørgsmål foreslår han, at vi stiller spørgsmål som "Hvad skal vi vælge som vores mest presserende problemer, [hvordan opstod de (er gledet ud af den i øvrigt udmærkede danske oversættelse)], og hvilke veje kan vi gå for at løse dem?" Dét er et rationelt spørgsmål, som hver generation ifølge Popper har en art forpligtelse til at stille sig selv. Og det er præcist også dette spørgsmål, som er Poppers anliggende i Det åbne samfund og dets fjender.

Problemet i begyndelsen af 1940'erne, hvor Popper skriver Det äbne samfund og dets fjender, er uden sam- 
menligning de nazistiske, fascistiske og til dels også de kommunistiske samfund, som er skudt op i specielt Europa. Med en samlebetegnelse kalder Popper disse samfund og lignende historiske eksempler for lukkede samfund. Et lukket samfund er et samfund fyldt med tabuer og forudgivne sandheder i forhold til, hvordan samfundet skal indrettes. I kontrast til dette lukkede og totalitære samfund står det åbne samfund. Her er tabuerne udskiftet med kritik, og totalitarismen med demokratiet.

Ifølge Popper går de lukkede samfunds intellektuelle rødder langt tilbage - faktisk helt tilbage til Heraklits konstatering af, at alt flyder. Det er nemlig i videretænkningen af dette brud med kosmostankegangen, at historicismen opstår - og det er historicismen, der ifølge Popper er den intellektuelle rod til de lukkede samfund. Historicismen bygger på forestillingen om, at historien udvikler sig efter et på forhånd fastlagt skema. Historicister mener derfor også kun, at det kan lade sig gøre at lave en holdbar og ordentlig samfundsindretning, hvis den bringes $\mathrm{i}$ overensstemmelse med historiens overordnede udviklingslinjer.

De tre mest indflydelsesrige historicister har ifølge Popper været Platon, Hegel og Marx, og Det àbne samfund og dets fjender former sig primært som læsninger af de tre 'intellektuelle forførers' forfatterskaber. Læsningerne er stærkt farvede af den forståelsesramme - det åbne kontra det lukkede samfund - som Popper lægger ned over historien. Men skønt der kan rejses kritik af fx hans meget bogstavelige læsning af Platons tekster, af hans rigide modstilling af helten Sokrates i forhold til skurken Platon samt af meget andet, så er der ingen tvivl om, at Popper har et solidt greb om sit stof (det vidner ikke mindst de godt 270 siders slutnoter, som værket er forsynet med, om). Og selvom læsningerne som sagt er farvede af den genfortælling af historien, som han etablerer, er de stadig særdeles læseværdige og tankevækkende. Ved siden af en lidt opskruet retorik, som ind imellem tager overhånd, byder Popper nemlig også læseren på interessante betragtninger over, hvad fx et godt samfund er.

Undervejs i Det åne samfund og det fjender laver Popper et hav af pragmatiske, men alligevel skarpe distinktioner, som når han $\mathrm{fx}$ skelner mellem et demokratisk styre og et diktatur: "... vi kan skelne mellem to hovedtyper af regeringer. Den første type består af regeringer, som vi kan slippe af med uden blodsudgydelse - for eksempel ved hjælp af almindelige valg; det vil sige, at samfundsinstitutionerne sørger for midler, hvormed de herskende kan afsættes af de beherskede, og samfundstraditionerne sikrer, at disse institutioner ikke let kan ødelægges af dem, der har magten. Den anden type består af regeringer, som de beherskede ikke kan slippe af med, bortset fra ved hjælp af en succesfuld revolution - det vil i de fleste tilfælde sige slet ikke. Jeg foreslår termen 'demokrati' for den første type, og termen 'tyranni' eller 'diktatur' for en regering af den anden 
type." (bind 1, s. 144-45) Det er dog langt fra alle distinktioner i værket, der er lige så elegante som dette eksempel. Fx er det ikke elegance, men derimod de manglende nuancer (dikteret af den kontekst, han taler ind i), der springer i øjnene, når Popper skelner mellem de gode og de onde, mellem heltene og skurkene i historien. Mens som omtalt Platon fx opfattes som en skurk, så fremhæver Popper modsat Sokrates som en helt. Hvor Platon nemlig mener, at han kan nå til sikker viden om det, der er, så tager Popper Sokrates' insistering på, at han ikke ved noget, meget bogstavelig. Den passer også godt til hans egen samfundstænkning i Det åbne samfund og dets fjender, der netop bygger på fallibilisme - altså på den antagelse, at vi som mennesker altid vil være fejlbarlige, at vores erkendelsesevne er begrænset. Det er fx grunden til, at han i værket advarer os imod at kaste os ud $i$ alt for store samfundsomvæltninger. Der vil nemlig altid være uintenderede bivirkninger forbundet med menneskelige handlinger, og jo mere omfattende handlingerne er, desto mere omfattende vil også de uintenderede bivirkninger være. Så skønt Popper mener, at meget kunne være bedre i samfundet - at der fx kunne være en højere grad af lighed borgerne imellem - så advarer han imod at lave en hel masse om på én gang. I stedet foreslår han, at vi arbejder os langsomt frem ved hjælp af det, han kalder for 'skridtvis socialt ingeniørarbejde'.

Den sociale ingeniør, der går forsigtigt frem, er derfor en anden af Poppers helte, mens historicisten omvendt opfattes som en skurk. I stedet for at spørge til samfundsinstitutionernes sandhedskarakter, til deres overensstemmelse med historiens love, som historicisten gør, spørger den sociale ingeniør nemlig til samfundsinstitutionernes evne til at tilvejebringe et bedre samfund. Og mens historicisten ønsker at bringe institutionerne $\mathrm{i}$ overensstemmelse med historiens bevægelse, med historiens mål - noget Popper af to grunde afviser kan lade sig gøre, nemlig dels pga. vores manglende erkendelsesevne og dels pga. historiens manglende ikkemenneskeskabte mening - så arbejder den sociale ingeniør pragmatisk på at forbedre institutionerne, så de kan virke til gavn for de mål, man har sat sig i det konkrete samfund.

Opgøret med historicismen er et hovedanliggende i Det åbne samfund og dets fjender, og der er stadig meget at hente i dette opgør. Helt aktuelt - ikke mindst med 11. september sidste år in mente - er det dog Poppers forsvar for tolerance, frihed og åbenhed, altså for det åbne samfund, der først og fremmest fortjener opmærksomhed. Også hans diskussioner af, hvor frihedens, tolerancens og åbenhedens grænser går, er interessante. Skønt Popper nemlig hylder det åbne samfunds frihed, tolerance og åbenhed, er han ikke naiv. Han skriver fx, at det er frihedens paradoks, at friheden må begrænses for at kunne udfoldes: Total frihed vil altid slå om $i$ sin modsætning, i ufrihed. Ligeledes ser han ingen grund til, at vi skal tolerere intolerance eller totalitarisme. Han ville uden tvivl nægte at godtage, at det 
fx skulle være intolerant eller antidemokratisk at forbyde Hizb-ut-Tahrir og andre erklærede intolerante og antidemokratiske foretagenders aktiviteter i fx Danmark. Han ville i stedet argumentere for, at de åbne samfund aktivt måtte bekæmpe den slags apologeter for det lukkede samfund - kun ved at sætte grænser for friheden kan vi nemlig bevare den!

\section{Mads P. Sorensen}

Den borgerlige offentligheds genkomst...

Christine Antorini, Henrik Dahl, Lars Goldschmidt, Det ny systemskifte, Gyldendal. 241 sider, 240,- kr.

Når man vil anmelde aktuelle debatbøger $i$ et tidsskrift med lang produktionstid, har alle dagbladene i sagens natur været på banen for længst. I dette tilfælde er det faktisk så længe siden, at forlaget sendte et eksemplar af 2. oplag til redaktionen, hvor citater fra dagbladenes anmeldelser er trykt på bagklappen. Ud over de obligatoriske tillægsord får vi her at vide, at bogen leverer opskriften til et mere saftigt og ægte dansk politisk landskab, at den bringer en advarsel, der bør tages alvorligt, og at den sætter ord på vores frustration over ikke at føle os som medlemmer af det politiske system. Det, man især vil huske fra debatten omkring udgivelsen, er omtalen af det provokerende forslag til en ny opdeling af de politiske partier, der bryder med klassesamfundet forældede partiskel. I stedet foreslår forfatterne en opdeling, der er mere eller mindre direkte baseret på Henrik Dahls Bourdieu-inspirerede segmentopdeling af befolkningen i fire 'verdenshjørner', som han lancerede i bogen Hvis din nabo var en bil. Især idéen om at opsplitte socialdemokratiet og fusionere den ene halvdel med Dansk Folkeparti under betegnelsen 'Hjemstavnspartiet' var et slag i den politiske bolledej, som skaffede bogen opmærksomhed lige efter udgivelsen.

Om det er udtryk for nyhedsmediernes egnethedskriterier eller om man bare kun har gidet læse det sidste kapitel, skal jeg ikke kunne sige. Men det er egentlig lidt ærgerligt, at debatten kommer til at handle om den slags spil med etiketterne, når der er langt mere saft $\mathrm{i}$ bogens påstand om, at forestillingen om national suverænitet ikke blot er en hæmsko for en positiv demokratisk udvikling, men tillige har været en illusion siden 1864, og heldigvis for det, for Danmark har fået velstand og sikkerhed gennem bevidst valgt suverænitetsafgivelse. Eller lige så vigtigt: at dominerende politiske tendenser modarbejder sammenhængskraften i samfundet ved at spille samfundsgrupper ud mod hinanden. Det er ganske vist ikke enestående nyt i debatten, men det er spørgsmål, som nyhedsmedierne ofte omgås med en ildtang ud fra den implicitte antagelse, at det ene argument jo kan være lige så godt som det andet, og man skal jo dele sol og vind lige, når de politiske kamphaner er kørt i stilling. At det ene argument netop ikke kan være lige så godt som det andet, er ellers i bedste oplysningstradition forfatternes helt 